\title{
The Role of Technology, Organization, and Environment Factors in Enterprise Resource Planning Implementation Success in Jordan
}

\author{
Mohammad Issa Al-Zoubi ${ }^{1}$ \\ ${ }^{1}$ Teaching Assistant, Department of MIS, Faculty of Administrative and Financial Sciences, Irbid National \\ University, Jordan \\ Correspondence: Mohammad Issa Al-Zoubi, Teaching Assistant, Department of MIS, Faculty of Administrative \\ and Financial Sciences, Irbid National University, Jordan.
}

\author{
Received: May 31, 2018 \\ Accepted: July 6, 2018 \\ Online Published: July 19, 2018 \\ doi:10.5539/ibr.v11n8p48 \\ URL: https://doi.org/10.5539/ibr.v11n8p48
}

\begin{abstract}
In many ways, the application of Enterprise Resource Planning (ERP) systems is useful. In today's business arena, ERP is regarded as a necessity. Implementation of ERP is costly and requires a lot of efforts but in Jordanian organizations, its success rate has been unsatisfactory. Hence, this study attempts to identify factors linked to implementation success of ERP in Jordan. The strategic factors are examined and they include technology adoption, web site service, competitive, top management support, change management, business process management, and trust. Questionnaires were distributed to ERP users in Jordanian firms which returned 141 responses which were analyzed. The results show significant linkage between technology adoption, web site service, competitive, top management support, change management, and business process management, and ERP implementation success. Nonetheless, the findings do not support the linkage between business process management and ERP implementation success. The findings show that firms can leverage TOE for improving ERP's implementation success to gain the anticipated benefits. Also, there is possibility that different critical success factors have different impacts on ERP benefits. Such finding expands the supposition of TOE theory that resources generate competitive advantages. This paper adds to researches on ERP by providing further evidence of the differing impacts of TOE on the successful implementation of ERP.
\end{abstract}

Keywords: trust, business planning, organization, technology, environment, enterprise resource planning

\section{Introduction}

The phenomenon of globalization in addition to increasing competition in the market can be a threat to organizations. As a respond to this threat, enterprise resource planning (ERP) is implemented (Taube \& Gargeya, 2005 and Dong-Wook, 2018). Systems of ERP are now crucial to companies that attempt to obtain competitive advantages which include reduction of cost, improvements of business processes, integration of operations and departments all of which assist in improving the organizations in terms of their effectiveness and competitiveness (Vlachos, 2006). Somehow, to be implemented, ERP needs substantial amount of financial resources while also complicated, challenging as well as lengthy. Also, the success rate of ERP particularly in the context of Jordan is very low. Relevantly, Indihar $S^{\nu}$ temberger and Kovac ${ }^{`}$ ic ${ }^{\nu}$ (2008) mentioned the risk of losing competitive advantage by having flexibly customized business processes as another disadvantage (Damijan Ž, Andrej K, and Mojca, 2009).

System of ERP is a standardized mass-produced package of information technology (IT) which offers the first actual prospect for modern organizations in integrating the processes and functions of their business (Klaus et al., 2000; Davenport, 2000). ERP comprises software commonly used all over the world among organizations that seek to, among others, change their outdated legacy systems, achieve strategic advantage, and enhance inter- and intra-operational efficiency (Davenport, 1998; Ifinedo, 2006a). ERP is essentially an application package which combines all linking organizational divisions such as human resource, production, marketing and so forth. The system links activities of front-office and those of back-office in-house and external supply chain operations (Yang \& Su, 2009). Still, Shao et al. (2012) reported failure among many companies in attaining the anticipated benefits of ERP even after they have implemented it for more than a decade.

Several studies (e.g., Ein-Dor \& Segev, 1978; Thong et al., 1996; Bajwa et al., 1998) have identified a vast range of contingency factors which have positive impact on the IT systems success. Among these factors are: organizational 
culture, size of organization, management of change, structure, business process management, top management support, internal IT support, and external (Competitive/ Trust). The past works have presented data on the impacts of some of the aforementioned contingency factors on the application of IT. Still, there should be caution when making generalization on findings and inferences to all contexts. Among the most extensively cited positive impacts in the success of newly spreading IT systems are top management support and engagement of quality vendors and consultants (Attewell, 1992; Bajwa et al., 1998; Wang \& Chen, 2006). Furthermore, researches on the interaction between some of these mentioned factors and the success of ERP are still uncommon.

As indicated by Wilson (2012), the interrelationship between the organization and its connected parts is crucial or otherwise, it would be difficult if not impossible for businesses to establish dynamic interaction with their customers, suppliers or even the environment. Furthermore, Paradice (2009) and Wilson (2012) noted the necessity to have a comprehensive outlook pertaining to the interrelationships that are present between organizations, technology and the environment when addressing the effectiveness of ERP. As such, the effect of external trust of customers and the competitiveness of ERP which could guarantee the successful implementation of ERP for attaining the anticipated ERP benefits are investigated in this study.

Accordingly, TOE theory will be used in this study. Many studies have in fact employed this theory, particularly for the examination of the pre-implementation and implementation of some applications of IS, including ERP, as exemplified in the works by Bradford and Florin (2003), Zhu and Kraemer (2005), Al-Zoubi (2013), and that of Zhu et al. (2010). In addition, the applicability of contingency factors such as the technological, organizational, and external setting for the implementation of ERP and also benefit achievement have been expressed by several authors including Kouki et al. (2007), Kouki et al. (2010) as well as Schniederjans and Yadav (2013). The integration of TOE framework conjectured that various factors relating to organization will impact the implementation success of ERP.

The TOE framework is thus a fitting theoretical support as it recognizes the conceivable antecedents, and this could impart influence on the success of post-implementation. In this regard, based on the past works, it appears that all the ERP CSFs in the stage of post-implementation under the factors of external environment have been classed into three factors as follows: ERP external pressure, ERP external consultant support, and external trust. Albeit this classification, their relationships with post-implementation success are yet to be investigated empirically( Soltan, Jusoh, and Bagheri , 2015).

A number of antecedent factors have been found to be drivers to innovation as a whole, specifically the uptake of ERP. These antecedent factors include technological factors, organizational factors, and external/environmental factors (Nejib, 2013; Soltan et al., 2015; Al-Zoubi, 2013; Schniederjans \& Yadav, 2013; Shaul \& Tauber, 2013). The literature covering these variables is vast but some scholars (e.g., Zhu et al., 2010; Shaul \& Tauber, 2013; Soltan et al., 2015; Ononiwu, 2013; Nejib, 2013; Schniederjans \& Yadav, 2013) reported the lack in empirical works and comprehension toward the ERP antecedents. These authors also reported an inconsistency of results across diverse environments of business which may be attributed to the differences of size, countries, and type of industry. Jarrar et al. (2000) and Soltan et al. (2015) for instance, documented that the acceptance of new innovation among small business organizations is dictated by internally essential factors such as management of business processes and support from top management. Somehow, as stressed in the work of Soltan et al. (2015), the process of deciding on new technology adoption appears to be more influenced by exogenous reasons as opposed to business related factors.

Notably, in the context of developed countries, several factors are viewed as less crucial including the factor of IT application. However, in the context of developing countries such as Jordan, the same factor is regarded as more important. For instance, Jordan is facing a considerable barrier to ERP seeing that the application of IT necessitates adequate financial resources so that it would be accessible (Al-Zoubi, 2016;Soltan et al. 2015). Hence, within the context of the developing countries, certain factors including technological factors have been stressed while others were not addressed. Among business organizations, this has become a significant barrier to their successful ERP. Also, some factors which are proposed in this study have not been adequately addressed in the literature. These include the factor of business process management which has been reported as a significant impacting factor.

\section{Literature Review}

ERP systems were first in practice since the beginning of the 90s, and the complicated implementations of these systems have been discussed in countless publications. Accordingly, professionals and academics alike have proposed several solutions to improve the performance of these systems. The literature on ERPs can be broken down into three different approaches.

The first approach focuses on the process of implementation. As reported by Parr and Shanks (2000), there has 
been considerable amount of efforts made in identifying and proposing several promising strategies. The proposed processes for attaining success in the first attempt have been ascertained (Donovan, 1999). Furthermore, the primary features of the essential tasks have been recommended (Al-Mudimigh et al., 2001). Some comprehensive works in this issue also have been carried out. For instance Luo and Strong (2004) analysed the boundary that is present between optimization and adaptation. Meanwhile, in the work by Esteves and Pastor (2002a), tools for evaluation of project were proposed.

Furthermore, some of the feasible avenues for best practices were explored by finding out the common points between successful companies and unsuccessful their counterparts (Mabert et al., 2003). Somehow, it appears that the use of ERP systems among organizations is increasingly more expansive. In Western Europe, more than $50 \%$ of the software licenses and maintenance revenues are related to accounts of ERP software and this rate is double the rate of the whole market of application software. The past few years have seen the implementation of ERP systems among countless of organizations, and as reported by Jacobson et al. (2007), through year 2011, the market for ERP remained expanding at a compounded annual growth rate of $11 \%$. Yen et al. (2002) predicted ERP to remain one of the biggest, swiftest expanding, and the biggest leaders in the application software industry in the following decade.

The second approach revolves around the analysis of the created organizational problems. The implementation of ERP causes the overturning of the organization's whole structure. From the pecking order of user involvement, Amoako-Gyampah (2004) highlighted the difference in viewpoints where some may contradict with others, and these have to be appropriately managed. An organization that is dispersed physically (mono- or multi-site) is compelled to make certain choices (Markus et al., 2000) because as mentioned by Davison (2002), issues related to culture may arise. Project management, particularly in terms of its specific procedure has been reevaluated in Agile management (Alleman, 2002) and Goal directed project management research (Metaxiotis et al., 2005). In addition, the size of company will expectedly raise some questions. This is because as indicated by Muscatello et al. (2003), enterprise of small or medium-size will not deal with implementation in the manner that multinational companies would.

The third approach relates to risk management. This is factored by the fact that ERP implementations have high uncertainty level. Several studies have examined the risks that are linked to these projects (Bernard et al., 2002; Huang et al., 2004). In these studies, the techniques of identification used are different based on the study itself. As reported by Zafiropoulos et al. (2005), managers are also provided with tools for identifying the risks most applicable to their projects.

\subsection{Technology Factors}

In the context of container shipping, the use of IT in the transportation of messages and in attaining smoother transport service are common, and this is caused by the institutional pressure of ERP (Lun et al., 2008; Makris et al., 2008; Wong et al., 2009). Accordingly, some researchers including Mokhtarian (2004) documented the crucial implication of the aforesaid development in e-shipping context. E-commerce and e-collaboration for instance, have the capacity to offer far more flexible and all-inclusive interaction and communication to companies that implemented ERP, with less financial cost incurred.

In addition, in terms of the application of radio frequency identification, the utilization of an innovative active system of FRID assists in the security improvement in commercial transportation system (Rizzo et al., 2011). Here, web databases are commonly employed to review records of previous transport and performance. This enables the arrangement and forecast of future flow of container for ERP. Within the context of companies involving in liner shipping, their website's service attributes have been broken down by AL-Zoubi and AL-Zawaideh (2017) and Lu et al. (2005) into four categories namely: response of customer, tracing, schedules of vessel, and electronic document services

Internet connection makes available a number of services including services of support, online transaction, and market information. The Internet also provides information on performance and equipment. Using the platforms of website, companies of container shipping provide to clients, particularly shippers and consignees rates of freight and time of transit (Al-Zoubi, 2014). Through these platforms, shippers and consignees could obtain the necessitated information regarding the consignments. Hence, using the website of carrier, schedules of sailing could be obtained by clients, and they can also track containers while also able to access online auctions (Lu et al., 2007).

As indicated by AL-Zoubi and AL-Zawaideh (2017), the design factor of website plays a major role in the attainment of e-Satisfaction level. $67 \%$ of change in the usage behaviors e-government to the website design factor. In particular, Perceived ease of use has positive impact on adoption if user only visits the website for obtaining information. However, if user visits the website for transaction purposes, then, this construct 
(perceived ease of use) might not impact the adoption rate within national e-Government portal of Jordan. AL-Zoubi and AL-Zawaideh (2017) indicated that satisfaction of Jordanians will increase from engaging in online governmental transactions.

\subsection{Organization Factors}

The implementation of ERP considerably affects the culture and structure of organization (Bosilj-Vuks ‘ic' \& Spremic', 2004; AL-Zoubi and Al-haija, 2018), and as indicated by Umble and Umble (2002), the success of implementation needs change in individuals, processes, departments, and in organization as well. Accordingly, change management has been reported by many studies as among the strongest factors which impact the success of ERP implementation, as can be referred in Table I. Change management involves management of human resource in addition to social changes that top management needs in introducing new processes and structures for equipping the organizational members in accepting changes and also in reducing their hesitancy in changing.

Change requires effective communication, and effective communication is necessary for all levels of business process, even when employees have no direct relation with BPM (Harmon, 2007). BPR also involves the transmission of power to companies of lower levels. Such transmission leads to adequate organizational culture and climate which causes employees to feel more accountable and important. In addition, BPR leads to changes of structure reflecting new tasks and responsibilities. Hence, La Rock (2003) reported the necessity to have a formal and clear delineation of every task and responsibility that is driven by the new process. Here, employees clearly are able to accomplish each new task. This also means that they are flexible enough to adapt to new changes in the organization, and demonstrate the willingness to learn.

Somehow, Hammer and Champy (2003) reported the common underestimation about teaching employees in organizations. In human resources, change management comprises activities including employee training particularly those impacted by change in business process, development of the needed new skills to cater to the new processes, and the development of systems of management for cultivating the values needed. Accordingly, Gargeya and Brady (2005) warned about the possible jeopardy to the anticipated success of the project when these vital factors within the project are not established. Subsequently, employees become less adversely impacted by the competitive business environment as the culture embraced by the organization has made them resilient. Somehow, Bashein and Markus (1994) and Umble and Umble (2002) stressed that everyone at every level must be educated.

As reported by many studies (e.g., Al-Mashari et al., 2003; Umble et al., 2003; Zhang et al., 2005, AL-Zoubi and Al-haija, 2018), top management support is an integral factor of ERP implementation success. Ngai et al. (2008) indicated top management support as crucial in the success of ERP implementation. This is because in general, ERP systems are large-scale and need a large amount of resources. Further, top management support should be given to the whole process of ERP implementation, not just at certain stages (Al-Mashari et al., 2003). In the implementation of ERP, top management support has two primary roles namely in the provision of the resources needed and in the provision of leadership (Zhang et al., 2005). In the implementation of ERP, Umble et al. (2003) and Dezdar and Ainin, (2011) reported that top management is responsible to communicate the company strategy to all members, create an understanding pertaining to the limits and abilities of the organization, show commitment, and formulate the rational objectives for the implementation of ERP

An initiative for transforming the process of business should come from the top, that is, from top management. This highlights the great importance of the transition of process ownership. Relevantly, Caron et al. (1994) indicated the importance of employees working with new processes in 'owning' these processes in order to assure success. Somehow, as mentioned by Hammer and Champy (2003), the majority of companies have inadequate owners of process, or, they appear to be defined to an insignificant extent, and this phenomenon is a resultant of the manner in which the traditional organization operates, which is not process oriented.

The processes of business are dispersed among the organizational confines. Hence, before reengineering, it is important to first identify the core business processes. As mentioned by Hammer and Champy (2003), organizations need to establish a process map with detailed business processes. This facilitates the understanding as well as sharing of the workflow in companies. A process relates to one or more tasks which change a set of inputs into a set of outputs specified. Process performance that is efficient and effective can be attained through the complete comprehension of its structure and the process flow. However, Kovac ${ }^{`} \mathrm{ic}^{`}{ }^{`}$ and Bosilj-Vuks ${ }^{`} \mathrm{ic}^{\prime}$ (2005) proposed that it is practical to identify just those activities as processes, which directly or indirectly lead to the generation of end products as added value.

Equally, Zairi and Sinclair (1995) reported that companies in practice outline their core and sub-processes prior to BPR. In their work, the authors found that the majority of the companies $(71 \%)$ have documented their core 
processes. On the other hand, $21 \%$ of the companies had planned to do the same. Such findings demonstrate the awareness of companies of the significance of delineating and documenting a process. Hence, the percentage of documented sub-processes was $45 \%$ which is much lower, while $37 \%$ of companies reported their intention to document.

BPR failure can be factored by business processes that are inappropriately defined (Grover et al., 1995). In fact, processes that are defined too broad or too narrow can cause BPR project to fail (Hall et al., 1993). As expressed in the work of Lok et al. (2005), reengineering overhauls the old information system. However, BPR has been known to include the old systems. Nonetheless, consistent developments have compelled companies to discard their old and adopt new environment with new hardware and software. Such change decreases the costs associated with software maintenance, while also allowing new features. As such, BPR can be jeopardized when documentation is missing or unfinished.

Considering that the goal is to adopt new processes rather than improving the old one, it will not be necessary to analyze and document the present processes that comprehensively. Still, Hammer and Champy (2003) stated that the processes should be defined only to a degree where they are fairly understood, and this becomes a basis for a delineation of totally new processes.

\subsection{Environment Factors}

Environmental aspects are just as important as other aspects (organizational aspects and technological aspects). The aspects of environment are associated with the domain where a company executes its business, and this includes the industry the company operates in, the company's competitors, and transactions of the company with the government (Pan \& Jang, 2008). In this study, external pressures and trust are regarded as two dimensions containing numerous CSFs for the success of ERP implementation. External pressures are competitive, regulatory pressures for the adoption of certain information technology. In this regard, competitive pressure and regulatory policy have been suggested to impact the adoption of ERP (Oliveira \& Martins, 2011).

The significance of competitive pressure for innovation adoption, in addition to regulatory environment have been documented by several past works (e.g., Zhu \& Kraemer, 2005; Zhu et al., 2003, 2004; Premkumar \& Ramamurthy, 1995; Iacovou et al., 1995). Furthermore, by way of strategic aspects of ERP systems, competitive pressure and regulatory environment appear to significantly affect the competitiveness of a company as opposed to other technical aspects (Yen \& Sheu, 2004). As frequently reported, the decision of an organization to invest in ERP technology is factored by the scrutiny of the competencies of IT that other organizations have and also by whether or not these organization have invested in ERP technology.

A positive relationship has been reported between external pressures, including competition, in past studies (Bradford \& Florin, 2003). However, on the success of ERP implementation, there are still too few studies that look into the relationship between regulatory pressure and implementation. The past works on information technology and ERP were mostly focusing on the system adoption (Pan \& Jang, 2008; Yen \& Sheu, 2004; Zhu et al., 2004). Still, it is possible that these pressures are also positively related to the success of ERP implementation. Here, the organization is not simply to just adopt an information technology, but to do so effectively and efficiently. This is for reducing pressure from competition and from that caused by regulatory pressure. The effect of external pressure is also supported by resource based view because for mitigating pressures from the outside, firms will try successful internal capacities and a successful implementation of ERP as well. Also, the incentive for first mover advantage and to reduce regulatory problems will eventually provide focus toward successfully overcoming obstacles with ERP implementation (Bradford \& Florin, 2003).

The factor that has not been addressed by the past works on ERP implementation success is the importance of trust. As previously mentioned, both user security and system security are crucial facets in success of ERP implementation (Goel et al., 2011). Trust between user, vendor, consultant and system is integral for the security of user and system. This study thus proposes the construct of trust to be among the key CSFs. The past works have highlighted the importance of relationships among people in an organization during the implementation of ERP (Amoako-Gyampah \& Salam, 2004). Further, the theories used such as social capital theory discusses the importance of trust in both an individual and organizational level for achieving competitive advantage. Somehow, studies that examined the notion of trust within the community of ERP and the trust of organization towards the system are still too few.

Many have provided the definition of trust, and this construct has been defined in the context of organization as well as individual. For instance, personality psychologists perceive the notion of trust as characteristic of a person (Rotter, 1971). Meanwhile, among economists and sociologists, the manner in which institutions are established for reducing uncertainty and increasing trust in certain business transactions was demonstrated 
(Bhattacharya et al., 1998; Zucker, 1986; Goffman, 1971).

Numerous types of trust have been investigated in studies. These trust types include: contractual trust, competence based trust, and goodwill based trust. Contractual trust relates to the confidence of trustor the trustee will or will not adhere to the agreements, while competence based trust is linked to the confidence of trustor that the trustee has the ability and readiness to do what they say they will do, whereas goodwill based trust is about the confidence of the trustor on whether or not the trustee will consider him (trustor) when making decisions (Chun Ha et al., 2011; Ireland \& Webb, 2007).

Trust of organization towards ERP system is essential during implementation and for the future. Organization that has no comprehension towards the system may not gain trust. In the work of Rotter (1954), trust is defined as external locus of control. Trust has also been linked to the theory of attribution proposed by Heider (1958). The theory posits that if something seems to be going wrong with the system, people might attribute the problem to the system itself, as opposed to attributing it to their own doing. This inhibits trust.

Also, a system with low level of trust is not likely to be implemented by organization anymore. This restricts the opportunity for the system to be successful. Somehow, the impact of system trust pertaining to the successful implementation of ERP has been insufficiently explored by the past works. A trust link that fails to provide information in a timely manner could harm the implementation of project or system, such as those of ERP which mainly focus on the collection and maintenance of communications inside and outside an organization.

\subsection{TOE Theory}

In TOE theory, technological factor takes into account the significance of technological insight in internal and external viewpoints, and it is also valuable in the promotion of organizational output (Tornatzky et al., 1990). In these technologies, the information system (IS) comprises various phases, from the basic capacities to organizational compatibility. These technical features will facilitate the foundation for achieving benefits for the organization. Technological factors have been reported as a potent predictor in both ERP pre-implementation or post-implementation (Chwelos et al., 2001; Zhu \& Kraemer, 2005).

Organizational factors comprise the existing resources to support and sustain the system acceptance and success. The managerial structure and the size of the organization, sensitive attributes of the organization which include the preparedness of the organization to support the arrangement, and an environment appropriate for system use (ERP system use) are also among the reported factors (Tornatzky et al., 1990; Chau \& Tam, 1997). Conducive environment should be provided by the organization to assure effective implementation of the system. Activities of organizational are thus essential for ERP in order to promote businesses.

The environmental factors include the outside environment of the organizations which could impact the system's post-implementation by the central organization. Considering that the implementation of ERP in the organization is a complicated function, the process of operation of ERP needs in-depth information that the organization may not have, that is, knowledge. It should also be noted that organizations are affected by the industries that relate with them, the competitors, and the organization's ability in obtaining the resources others supply.

Table 1. Constructs, supporting theory and literature

\begin{tabular}{|c|c|c|c|}
\hline Key & Construct & Theory & Supporting Literature \\
\hline EET & ERP External Trust & $\begin{array}{l}\text { Social capital theory, } \\
\text { attribution theory, TOE } \\
\text { theory }\end{array}$ & $\begin{array}{l}\text { Soltan et al. (2015); Gefen (2004); } \\
\text { Amoako-Gyampah and Salam (2004); White } \\
\text { (2008); Abdullah (2009); Supramaniam and } \\
\text { Kuppusamy (2011); Upadhyay et al. (2011); } \\
\text { Basu and Lederer (2011);Schniederjans and } \\
\text { Yadav (2013), Thi et al., 2014. }\end{array}$ \\
\hline EEP & $\begin{array}{l}\text { ERP External } \\
\text { Pressure }\end{array}$ & $\begin{array}{l}\text { Institutional theory, } \\
\text { resource based view, TOE } \\
\text { theory }\end{array}$ & $\begin{array}{l}\text { Soltan et al. (2015); Pan and Jang (2008);Zhu } \\
\text { and Kraemer (2005); Zhu (2004);Zhu et al. } \\
\text { (2004); Zhu et al. (2003); (Kouki et al., 2007; } \\
\text { Kouki et al., 2010); Nejib (2013); Schniederjans } \\
\text { and Yadav (2013); Shaul and Tauber (2013); } \\
\text { Al-Zoubi, 2016. }\end{array}$ \\
\hline EECS & $\begin{array}{l}\text { ERP External } \\
\text { Consultants Support }\end{array}$ & $\begin{array}{l}\text { Institutional theory, TOE } \\
\text { theory }\end{array}$ & $\begin{array}{l}\text { Soltan et al. (2015); Somers and Nelson (2004); } \\
\text { Kouki et al., (2007; Kouki et al., 2010); White } \\
\text { (2008); Kronbichler et al. (2009); Zhu et al. } \\
\text { (2010); Shaul and Tauber (2013); Ononiwu } \\
\text { (2013); Nejib (2013); Schniederjans and Yadav } \\
\text { (2013) }\end{array}$ \\
\hline
\end{tabular}




\section{Research Framework and Hypotheses Development}

Taking into account this study's purpose, and in accordance with ERP CSFs' classification by some works Dezdar and Ainin (2011); Soltan et al,.(2015); Damijan et al., (2009); Princely(2008) and Schniederjans and Yadav (2013), this study presents a research framework as shown in Fig. 1. Accordingly, the hypotheses below were developed:

\section{What are the factors that drive the enterprise resource planning implementation success among businesses in Jordan?}

H1: Technology factors are positively related with ERP implementation success.

$\mathrm{H} 2$ : Organization factors are positively related with ERP implementation success.

H3: Environment factors are positively related with ERP implementation success.

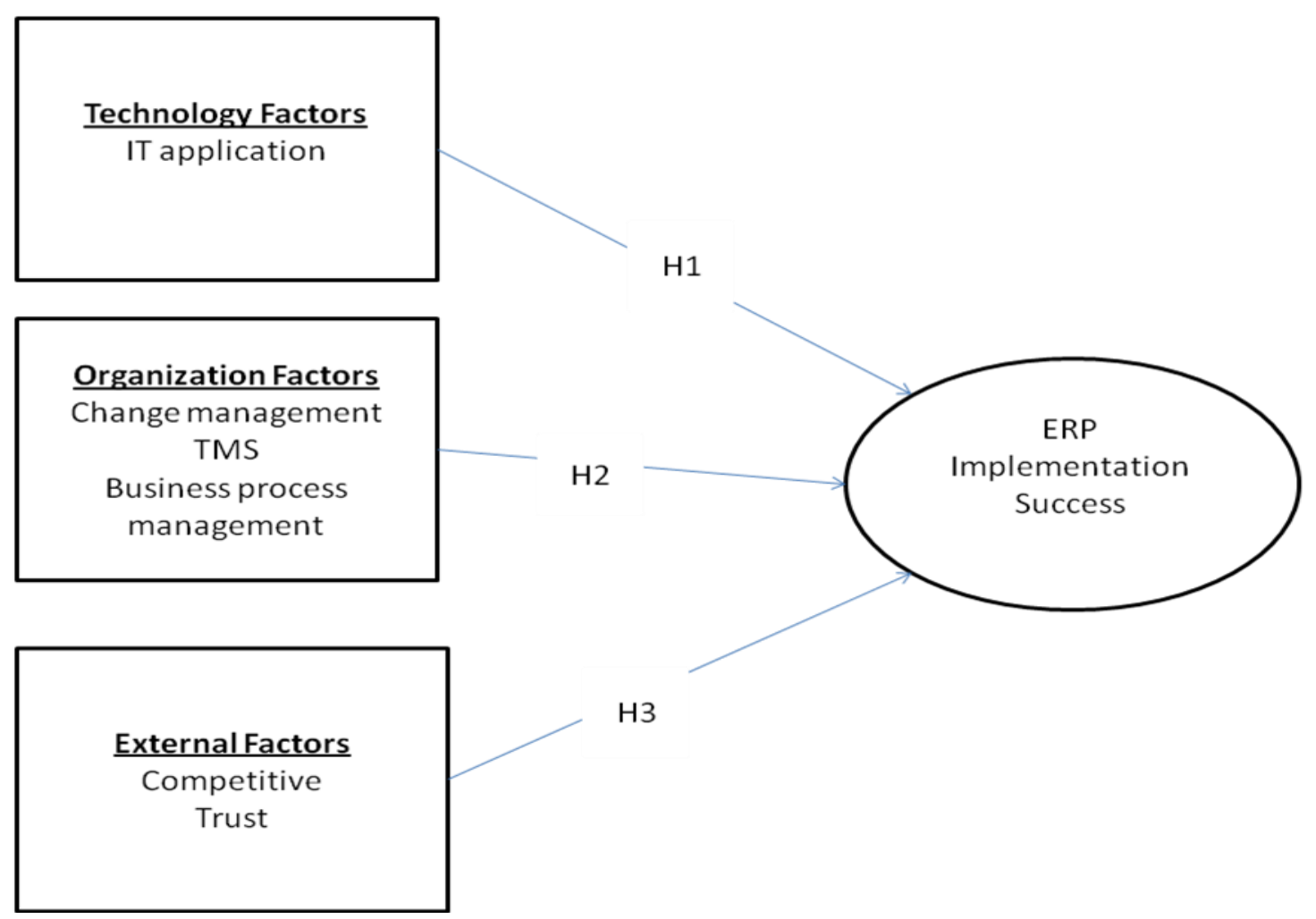

Figure 1. ERP implementation success model

\subsection{Population of Study}

Managers in Jordanian firms have been chosen as this study's target population. These firms comprise companies registered in the Chamber of Industry and Trade in Jordan. Managers in the sectors of service, industry, banking, and insurance comprise the study unit.

\section{Data Collection and Data Analysis}

A total of 290 firms were involved in the survey. A total of 141 responses were received in this study (48.6\% rate of response), and the data obtained were analysed using Statistical Package for Social Science (SPSS). In particular, this study attempts to determine the causal relationship among the variables as the framework is proposing.

The relationship between three independent variables (technology factors, organization factors, and environment factors) and one dependent variable (enterprise resource planning) was explored in this study. For this purpose, 5-points Likert scale was used in measuring these variables. For this scale, the range of score is from the score of 1 which denotes 'not applied at all' to the score of 5 which denotes 'totally applied.' Reliability and validity analyses were also performed in this study. In addition, this study used the descriptive analysis for providing the description on the characteristic of sample and the respondents to the questionnaires, and also the independent and dependent variables. The hypotheses were tested using multiple regression analysis. 


\subsection{Reliability and Validity}

Reliability analysis is associated with the evaluation of consistency level between multiple measurements of a variable. As for the analysis of validity, it concerns the degree to which a set of measures or a scale exactly symbolizes the construct (Hair et al., 1998). Validity has been explained by Blumberg et al. (2005) as the degree to which an instrument measures is anticipated to measure or what the researcher intends to measure. Cronbach's alpha coefficient was used to measure the instrument's reliability. As suggested by Bagozzi and Yi (1988), for all indicators or dimensional scales, the values of should be greater than the recommended value of 0.60 . The Cronbach's alpha results for the independent and dependent variables are shown in Table (2).

Table 2. Cronbach alpha for the TOE and ERP

\begin{tabular}{lcc}
\hline Variables & Number of items & Cronbach Alpha \\
\hline Web site service & 4 & 0.874 \\
Technology adoption & 4 & 0.877 \\
Change management & 2 & 0.856 \\
TMS & 4 & 0.911 \\
BPM & 3 & 0.798 \\
Competitive & 4 & 0.759 \\
Trust & 4 & 0.854 \\
ERP & 2 & 0.893 \\
\hline
\end{tabular}

For all the variables tested, the coefficients of Cronbach's alpha were greater than 0.60 . This demonstrates the reliability of the composite measure. Also, items that this study has chosen to measure the independent and dependent variables have already been validated and applied in past studies. Hence, the validity of the items is enhanced in this study. Furthermore, the faculty of business from six universities in Jordan reviewed the questionnaire items.

\subsection{Respondents Demographic Profile}

Table (3) presents the demographic profile of the study participants. As can be observed, the largest portion of respondents was male and employed as consulting engineers. Majority held bachelor degrees, and nearly half $(47.5 \%)$ had more than 15 years of experience.

Table 3. Description of the respondents demographic profiles

\begin{tabular}{llcc}
\hline Category & Category & Frequency & Percentage \% \\
\hline Gender & Males & 98 & 56.2 \\
& Females & 43 & 43.8 \\
experience & Total & 141 & 100 \\
& Less than 5 years & 28 & 19.9 \\
& 5-less than 10 years & 38 & 27 \\
& 10-less than 15 years & 8 & 5.6 \\
Job position & More than 15 years & 67 & 47.5 \\
& Total & 141 & 100 \\
& Consultant & 54 & 38.3 \\
Qualification & Consulting & 23 & 16.3 \\
& Total & 64 & 45.4 \\
& Diploma & 141 & 100 \\
& Bachelor & 2 & 1.4 \\
& Graduate studies & 120 & 85.1 \\
& Total & 19 & 13.5 \\
\hline
\end{tabular}

\subsection{Descriptive Analysis}

Table (4) shows the results of analysis. As can be seen, in the context of Jordan, organization factors are used to a substantial degree with the mean score of 3.75, denoting the importance of organization factors. Additionally, high level of presentation demonstrates the presence of positive attitude pertaining to the top management support processes. Somehow, this study found that the factors of technology, environment, and resource planning of enterprise to be moderate. This implies the current presence of TOE activities among Jordanian firms. These firms appear to concentrate on enterprise resource planning in preserving their competitive advantages. The items shown in Table (5) comprise the mean scores for the factors of technology, organization, environment, in addition to the items associated with enterprise resource planning items. 
Table 4. Overall mean and standard deviation of the study's variables

\begin{tabular}{|c|c|c|c|c|c|}
\hline \multirow{2}{*}{$\begin{array}{l}\text { Type of Variable } \\
\text { Independent }\end{array}$} & Mean & \multicolumn{2}{|l|}{ Standard Deviation } & \multirow{2}{*}{$\begin{array}{l}\text { Level } \\
\text { Moderate }\end{array}$} & Order \\
\hline & 3.3 & 0.75 & & & \\
\hline \multirow[t]{9}{*}{ Variables } & $\begin{array}{l}\text { Web } \quad \text { site } \\
\text { service }\end{array}$ & 0.7 & & Moderate & 1 \\
\hline & $\begin{array}{l}\text { Technology } \\
\text { adoption }\end{array}$ & 0.8 & & Moderate & 2 \\
\hline & $\underline{\mathrm{OF}}$ & 0.76 & & High & \\
\hline & 3.79 & 0.76 & & High & 3 \\
\hline & TMS & 0.85 & & High & 1 \\
\hline & $\mathrm{BPM}$ & 0.83 & & High & 2 \\
\hline & EF & 0.6 & & Moderate & \\
\hline & $\overline{\text { Competitive }}$ & 0.71 & & Moderate & 2 \\
\hline & Trust & 0.68 & & Moderate & 1 \\
\hline $\begin{array}{l}\text { Dependent } \\
\text { Variable }\end{array}$ & ERP & 0.82 & & Moderate & \\
\hline \multicolumn{6}{|c|}{ Table 5. Mean and standard deviation of the study's variables } \\
\hline \multicolumn{2}{|l|}{ Web Site Service } & Mean & SD & Level & Order \\
\hline \multicolumn{2}{|c|}{$\begin{array}{l}\text { My firm actively instructs customers about how to use } \\
\text { electronic commerce web sites }\end{array}$} & 3.15 & 1.16 & Moderate & 1 \\
\hline \multicolumn{2}{|c|}{$\begin{array}{l}\text { Customers frequently use my firm's web site to enquire about } \\
\text { sailing schedules online }\end{array}$} & 2.66 & 1.34 & Moderate & 2 \\
\hline \multicolumn{2}{|c|}{$\begin{array}{l}\text { Customers frequently use my firm's web site to book space for } \\
\text { containers online }\end{array}$} & 2.10 & 1.36 & Moderate & 4 \\
\hline \multicolumn{2}{|c|}{$\begin{array}{l}\text { My firm's web site system can help integrate our supply chain } \\
\text { partners }\end{array}$} & 2.5 & 1.22 & Moderate & 3 \\
\hline \multicolumn{2}{|c|}{ Technology Adoption } & Mean & SD & Level & Order \\
\hline \multicolumn{2}{|c|}{ My firm adopts advanced IT to control container flow } & 3.55 & 1.21 & Moderate & 1 \\
\hline \multicolumn{2}{|c|}{$\begin{array}{l}\text { My firm adopts electronic data interchange (EDI) to improve } \\
\text { transport operation efficiency }\end{array}$} & 3.43 & 1.11 & Moderate & 3 \\
\hline \multicolumn{2}{|c|}{$\begin{array}{l}\text { My firm adopts a customer relationship management (CRM) } \\
\text { system to collect market information and analyze it }\end{array}$} & 3.45 & 0.9 & Moderate & 2 \\
\hline \multicolumn{2}{|c|}{ My firm adopts online transactions to reduce operational costs } & 3.33 & 1.04 & Moderate & 4 \\
\hline \multicolumn{2}{|c|}{ Change Management (CM) } & Mean & SD & Level & Order \\
\hline \multicolumn{2}{|c|}{ Employees learning ability } & 3.79 & 1.15 & High & 2 \\
\hline \multicolumn{2}{|c|}{ Employees adaptability on different task } & 3.86 & 1.06 & High & 1 \\
\hline \multicolumn{2}{|c|}{ Top Management Support (TMS) } & Mean & SD & Level & Order \\
\hline $\begin{array}{l}\text { Top Management } \\
\text { ERP System }\end{array}$ & ts The Adoption And Use_Of Our & 4.15 & 0.97 & High & 1 \\
\hline Different Departme & e Of Equal Importance & 4.01 & 1.02 & High & 2 \\
\hline $\begin{array}{l}\text { Employees Are } \\
\text { Management Decid }\end{array}$ & $\begin{array}{l}\text { With The Changes That Top } \\
\text { ERP Issues }\end{array}$ & 3.77 & 1.17 & High & 4 \\
\hline $\begin{array}{l}\text { Top Managemen } \\
\text { Organization }\end{array}$ & Share Information In Our & 3.96 & 1.04 & High & 3 \\
\hline Business Process $\mathbf{N}$ & ement (BPM) & Mean & SD & Level & Order \\
\hline Defined business pr & owners & 3.44 & 1.21 & Moderate & 3 \\
\hline Defined business pr & & 3.86 & 1.03 & High & 2 \\
\hline Documented busine & cesses & 3.94 & 0.901 & High & 1 \\
\hline Competitive & & Mean & SD & Level & Order \\
\hline Competitive advant & the efficient logistics operations & 3.55 & 1.41 & Moderate & 1 \\
\hline Competitive advant & the effective ERP & 3.33 & 1.21 & Moderate & 2 \\
\hline Competitive advant & differentiating our ERP & 3.22 & 1.31 & Moderate & 3 \\
\hline Competitive advant & the reputation of our excellent ERP & 2.98 & 1.21 & Moderate & 4 \\
\hline Trust & & Mean & SD & Level & Order \\
\hline Trust to systems ha: & itive effect on ERP & 2.77 & 1.24 & Moderate & 4 \\
\hline Trust to vendors has & itive effect on ERP & 2.87 & 1.24 & Moderate & 3 \\
\hline $\begin{array}{l}\text { Trust towards ER } \\
\text { intention to use ERI }\end{array}$ & $\begin{array}{l}\text { tem has a positive effect on the } \\
\text { ms. }\end{array}$ & 2.91 & 1.31 & Moderate & 2 \\
\hline $\begin{array}{l}\text { Trust towards ERI } \\
\text { intention to use ERI }\end{array}$ & $\begin{array}{l}\text { dors has a positive effect on the } \\
\text { ms. }\end{array}$ & 2.99 & 1.05 & Moderate & 1 \\
\hline Enterprise Resour & nning (ERP ) & Mean & SD & Level & Order \\
\hline $\begin{array}{l}\text { ERP implementatic } \\
\text { performance }\end{array}$ & a positive influence on business & 3.92 & 1.06 & High & 1 \\
\hline ERP implementatio & ne with expected results & 3.89 & 1.58 & High & 2 \\
\hline
\end{tabular}




\section{Hypotheses Testing Results}

This study looks into the effect of the factors of technology (web site service and technology adoption), those of organization (change management, top management support, and business process management), and those of environment (competitive and trust) on resource planning of enterprise among firms in Jordan. Hence, the technique of multiple-regression was applied for hypotheses testing. Also, this study has chosen the value of 0.05 the level of significance $(\alpha-$ level). Further, the probability value (p-value) attained from test of statistical hypotheses is deemed as the decisive rule for the rejection of the null hypotheses (Creswell, 2009).

The obtained p-value of lower than or equal to $\alpha$ - level means that the null hypothesis is rejected while lending support to the alternative hypothesis. On the other hand, the obtained p-value of higher than the $\alpha$-level means failure to reject the null hypothesis while the alternative hypothesis will not be supported. This study also checked the normality of the independent variables and the non-presence of the problem of multi co-linearity (a case of multiple regression in which the independent variables have high correlation themselves). Pallant (2005) proposed that the majority of the values inside the ranges which are satisfactory for normality (i.e. -1.0 to +1.0 ). Hence, this study also examined the skewness and Variance Inflation Factor (VIF). The results are shown in Table (6).

Table 6. Skewness and VIF for the independent variables

\begin{tabular}{lcc}
\hline Variables & Skewness & VIF \\
\hline Web site service & -0.33 & 1.71 \\
Technology adoption & -0.31 & 1.66 \\
Change management (CM) & -0.65 & 2.46 \\
Top Management Support (TMS) & -1.00 & 2.42 \\
Business Process Management (BPM) & -0.501 & 2.95 \\
Competitive & -0.41 & 1.89 \\
Trust & -0.37 & 2.45 \\
\hline
\end{tabular}

Table 6 evidences that the values of skewness were in the range of normal values $(-1.0$ to +1.0$)$. This demonstrates the normality of the independent variables' data. The values of VIF appeared to be lower than the critical value (10). This means that there is no problem of multi co-linearity among the independent variables.

\subsection{Conceptual Framework}

This study majorly aimed to find out the factors viewed as having linkage to the implementation success of resource planning. This study identified 7 factors from the relevant literature. In addition, a conceptual model was constructed in this study. This model examines the implementations of enterprise resource planning (ERP) at firm level. The framework employed in this study was grounded upon the Technology-Organisation-External (TOE) theoretical framework from Tornatzky and Fleischer (1990). Figure 1 highlights the factors of TOE derived from the factor analysis.

This study attempts to determine the factors that are linked to implementation success of resource planning. Hence, this study has chosen to employ linear regression rather than the regression model ordered.

\subsection{Hypothesis}

The research question in this study relates to the relationship between the factors of TOE and the implementation success of ERP among businesses in Jordan. For this purpose, this study performed the analyses of linear regression for examining the relationship between the dependent and independent variables. Table (7) highlights the results of hypothesis testing.

Table 7. Result for the study model (a, b, and c)

A)

Model Summary

\begin{tabular}{|c|c|c|c|c|}
\hline Model & $\mathbf{R}$ & R Square & $\begin{array}{c}\text { Adjusted R } \\
\text { Square }\end{array}$ & $\begin{array}{l}\text { Std. Error of } \\
\text { the Estimate }\end{array}$ \\
\hline 1 & $.791^{\mathrm{a}}$ & .642 & .641 & .06170 \\
\hline
\end{tabular}


B)

\begin{tabular}{|ll|r|r|r|c|c|}
\hline \multicolumn{7}{|c|}{ ANOVA $^{\mathbf{0}}$} \\
\hline 1 & Redel & Sum of Squares & df & Mean Square & F & Sig. \\
\hline & Residual & 53.044 & 7 & 7.578 & 141.191 & $.000^{2}$ \\
& Total & 3.254 & 387 & .008 & & \\
\hline
\end{tabular}

a. Predictors: (Constant), Trust, TA, Competitive, TMS, BPM, CM, WSS

b. Dependent Variable: ERP

C)

Coefficients $^{\mathrm{a}}$

\begin{tabular}{|c|c|c|c|c|c|c|}
\hline \multirow{2}{*}{\multicolumn{2}{|c|}{ Model }} & \multicolumn{2}{|c|}{ Unstandardized Coefficients } & \multirow{2}{*}{$\begin{array}{l}\text { Standardized } \\
\text { Coefficients } \\
\text { Beta }\end{array}$} & \multirow[b]{2}{*}{$\mathrm{t}$} & \multirow[b]{2}{*}{ Sig. } \\
\hline & & B & Std. Error & & & \\
\hline \multirow[t]{8}{*}{1} & (Constant) & .362 & .050 & & 7.187 & .000 \\
\hline & WSS & $-.038-$ & .016 & .255 & 2.327 & .020 \\
\hline & BPM & .018 & .013 & .027 & 1.385 & .167 \\
\hline & TA & .198 & .006 & .430 & 3.494 & .000 \\
\hline & $\mathrm{CM}$ & .280 & .010 & .511 & 2.975 & .000 \\
\hline & TMS & .200 & .005 & .516 & 4.729 & .000 \\
\hline & Competitive & .260 & .008 & .410 & 3.264 & .000 \\
\hline & Trust & $-.013-$ & .006 & - & $-2.142-$ & .033 \\
\hline
\end{tabular}

a. Dependent Variable: ERP

As can be observed in Table (7), a positive correlation appears to exist between TOE and ERP among firms in Jordan $(r=0.791)$. This denotes that both the independent variables and dependent variable change in the exact direction. Furthermore, the R Square value denotes the variation fraction in the variable of ERP which is explainable using 7 processes of TOE. Accordingly, $64.2 \%$ of the variability of ERP was explainable using TOE variables. Meanwhile, the data show F-ratio of 141.191 which appears to be significant at $\mathrm{p}<0.05(\mathrm{sig}=0.000)$. This implies a statistically significant effect of TOE on ERP. The alternative hypothesis is thus accepted.

As can be seen in the findings, with a significance level of (0.000), the obtained $t$ value for service of website was 2.327, 3.494 for technology adoption, 2.975 for change management, 4.729 for top management support, 3.261 for competitive, and -2.142 for trust. For Business Process Management, the $\mathrm{t}$ value obtained was 1.385 with a level of not significance of 0.167 .

As shown, the construct of trust obtained negative $t$ value. This means that trust leads to the decrease in ERP value. The decrease amount is symbolized by the $\beta$ coefficients $(0.027)$. This implies that an increase in ERP by one unit is associated with a decrease of 0.027 in trust. Furthermore, the value of $\beta$ was correspondingly 0.255 , $0.430,0.511,0.516,0.027$, and 0.410 . This demonstrates top management support as the most prominent ERP predictor among the surveyed Jordanian firms, followed by TOE.

This section generally provides the outcomes from the analyses of binary linear regression for identifying the factors seen as having linkage to the implementation success of ERP. Accordingly, the theory of technological diffusion guided the construction of framework for evaluating the implementation success of ERP. This framework employed 7 factors that are linked to ERP implementation success among firms. A total of 6 variables appeared to have linkage with ERP implementation success. From these 6 variables, 2 were technological context variables while another 2 were organizational context variables. The other variable was external context variable.

\section{Discussion and Conclusions}

The present study attempts to find out the factors linked to ERP implementation success in the context of Jordan. Hence, this section will present the results of the analysis. This study applied linear regression in investigating the relation of technological, organisational and external factors as independent variables with numerous ERP implementation success. 
This study finds 6 of the 7 factors to have considerable linkage to ERP implementation success. Service of website, technology adoption, top management support, change management, competitive, and trust appear to be significant determinants of ERP successful implementation. Furthermore, among businesses in Jordan, the factors of technology, organisation and outside environment appear to considerably affect ERP implementation success.

Furthermore, greater level of explicitness and technology amassing can assist in the technological knowledge transfer within the organization. These factors can also increase the capacity in the implementation of technologies successfully. Through encouragement or support to their employees in ERP implementation and by providing them with training and education, firms in Jordan are able to increase their capacities in technological implementation. Also, as expected, factors of TOE show their significance. Based on the outcomes, the significant role of TOE in ERP implementation success is affirmed and this finding is in agreement with the past relevant works including Soltan et al. (2015), Pan and Jang (2008), Zhu and Kraemer (2005), Zhu (2004), Zhu et al. (2004), Zhu et al. (2003), Kouki et al. (2007), Kouki et al. (2010), Nejib (2013), Schniederjans and Yadav (2013) and Shaul and Tauber (2013).

Insignificant linkage between IT application (website service, and technology adoption) and ERP implementation success was found in this study. Such finding may be factored by dissimilarities in the respondents' business scales. This study primarily involves container shipping agencies which appear to be firm's managers with successful ERP implementation. These managers were from diverse business sectors in Jordan. Comparatively, the past works were primarily concentrating on large firms (e.g. Po-Hsing al., 2015). In addition, IT investment may have a short-term adverse impact on ERP implementation success. As such, it is necessary to evaluate the effect on ERP improvement of firm from the perspective of a long-term. Also, such insignificant linkage in website service and adoption of technology with ERP corresponds with the experiences of failure in some information services, for instance, customer relationship management systems (see Kouki et al., 2007; Kouki et al., 2010; White, 2008; Thi et al., 2014).

This study provides affirmation on the effect of all presented organization factors, the effect of top management support, change management and BPM, on ERP implementation success. In the past works, the mentioned factors are among the most important TOE and positively affect ERP implementation success. Hence, they hold significance in the projects of ERP systems implementation. The results that this study has obtained are also in support to the significance of top management's perception. This implies that if BPM is considered to be a foundation for business change, and this generates a solid and desirable impact on a successful implementation of ERP.

There are practical implications of the outcomes obtained by this study. First, it would be invaluable for companies to regard BPM as a foundation for a business change and increase its usage. Such increase in usage brings a solid as well as desirable impact on a successful ERP implementation. All success factors that this study has scrutinized should be considered. Hence, organizations should have understanding of them and take them into account. Such awareness will generate desirable impact on a successful ERP implementation. Furthermore, organizations should refrain from dismissing their ERP implementation project too early, owing to the fact that the anticipated outcomes could take time before they materialize. In fact, ERP projects can still be fruitful even if they do not fulfil what the organization requires. Hence, organizations should properly define what constitutes project success by going beyond the requirement of time, budget, and specification (Zhang et al., 2005; Damijan, 2009). Also, ERP can still lead to greater business effectiveness even if its implementation is not as efficient. It is common for organization to want to make deduction that projects are good when it shows results. Hence, organizations would increase activity and investment in such projects (Lok et al., 2005; Damijan, 2009).

Also, the factor of trust to businesses shows considerable linkage to the success of ERP implementation. Similarly, some authors found this factor to play a major role in the initiation of countless ERP implementation success (e.g. Dara., 2013; Dong-Wook, 2018).

Competition is among the key facilitators of ERP implementation. In the past works, this construct was reported as a noteworthy variable that initiates ERP implementation (e.g., Dara, 2013; Dong-Wook, 2018).

A new approach to TOE theory has been proposed in this study. In particular, this study highlights the crucial roles played by several new environmental antecedents of ERP implementation success. New environmental factors are thus presented in this work namely the factors of competitive and trust. Such addition enriches the body of knowledge concerning the role of the factors of environment in the effective implementation and preservation of ERP in implementation success. In general, there are a number of contributions that this study brings to the community of ERP highlighted next. 
Firstly, this study adds to the researches in the domain of ERP by looking into the impact of ERP outside factors' critical factors on the implementation benefits of ERP. Secondly, this study adds to the theory of TOE by hypothetically demonstrating the great prominence of ERP consultant support, ERP external pressure, and competitive and trust over environmental critical resources to enhancing the benefits of ERP. This study's findings also show the ability of firms in leveraging CSFs for the improvement of success of ERP in implementation success to attain the anticipated benefits. Moreover, this study is able to show that different critical success factors may impact different impacts on ERP benefits. This notion is an expansion of the general supposition of TOE theory that resources generate competitive advantages. Next, further evidence is presented by this study, concerning the different impacts of CSFs on the implementation success of ERP.

\section{Limitations and Future Directions}

Several limitations were faced while performing this study and the first one relates to the issue of time and effort. As mentioned, this study was conducted on 290 ASE listed Jordanian firms (ASE, 2010. However, the researchers could not distribute the questionnaire to the whole population and gather more responses. In particular, this study employed email as an attempt to ease the response attainment. Unfortunately, this method appeared to be ineffective because the majority of the firms preferred to receive hard copies by way of drop and collect method. Another limitation to this study was poor cooperation given by some firms because of the issues relating to privacy even though the items of the questionnaire were constructed in a way that did impact the privacy of the firm. Hence, some firms declined the questionnaire right away. On the other hand, some firms agreed to participate, but they allowed only a specified amount of copies to be distributed to certain employees.

However, the researchers took steps to resolve these limitations. Firstly, a sample representing the entire population was chosen. In addition, to increase trust of respondents and assure privacy, visits and quick interviews were carried out for the purpose of explaining the aim of the questionnaire and the study. In addition, the questionnaires were personally handed to the respondents and the completed questionnaires were personally collected from them. The researchers also made the effort to acquire the overall background of consulting firms involved in this study.

\section{References}

Alleman, G. B. (2002). "Agile project management methods for ERP: how to apply agile processes to complex cots projects and live to tell about it". Extreme Programming and Agile Methods - XP/Agile Universe, Springer-Verlag, Chicago, IL, pp. 70-88. https://doi.org/10.1007/3-540-45672-4_8

Al-Mashari, M. (2003). “A process change-oriented model for ERP application”. International Journal of Human-computer Interaction, 16(1), 39-55. https://doi.org/10.1207/S15327590IJHC1601_4

AL-MUDIMIGH, A., ZAIRI, M., \& AL-MASHARI, M. (2001). ERP Software Implementation: An Integrative Framework. European Journal of Information Systems, 10, 216-226. https://doi.org/10.1057/palgrave.ejis.3000406

Al-Zoubi, M. (2013). Predicting E- Business Adoption Through Integrating the Constructs of the Rogers's Diffusion of Innovation Theory Combined with Technology-Organization-Environment Model. International Journal of Advanced Computer Research, 3, 13.

Al-Zoubi, M. (2016). A Study on the Usage of Arabic Commerce Websites Services among Uae Citizens. Account and Financial Management Journal, 1, 401-407. https://doi.org/10.18535/afmj/v1i6.04

Al-Zoubi, M. (2016). Customer Relationship Marketing: Its Impact On Customer Loyalty. International Journal of Engineering Researches and Management Studies, 3(9), 59-69.

Al-Zoubi, M. (2016). Factors That Influence Mobile Learning Acceptance in Higher Education Institutions in Dubai. Account and Financial Management Journal, 1, 392-400. https://doi.org/10.18535/afmj/v1i6.03

AL-Zoubi, M., \& Al-haija, A. (2018). Organization Factors For ERP Projects In A Developing Country: A Case Study Jordan. International Business Research, 11(8). https://doi.org/10.5539/ibr.v11n8p1

AL-Zoubi, M., \& AL-Zawaideh, F. (2017). Web- Based For Successful E-Government Adoption: The Jordan National E-Government Portal. International Review of Management and Business Research, 6(1), 320.

Amoako-Gyampah, K., \& Salam, A. F. (2004). "An extension of the technology acceptance model in an ERP implementation environment". Information and Management, 41(6), 731-745. https://doi.org/10.1016/j.im.2003.08.010

Attewell, P. (1992). "Technology diffusion and organizational learning: the case of business computing". 
Organization Science, 3(1), 1-19. https://doi.org/10.1287/orsc.3.1.1

Bagozzi, R., \& Yi, Y. (1988). On the evaluation of structural evaluation models. Journal of the Academy of Marketing Science, 16(1), 74-94. https://doi.org/10.1007/BF02723327

Bajwa, D., Rai, A., \& Brennan, I. (1998). "Key antecedents of executive information system success: a path analytic approach". Decision Support Systems, 22(1), 31-43. https://doi.org/10.1016/S0167-9236(97)00032-8

Bashein, B. J., \& Markus, M. L. (1994). "Preconditions for BPR success: and how to prevent failures". Information Systems Management, 11(2), 7-13. https://doi.org/10.1080/10580539408964630

Bernard, J. G., Rivard, S., \& Aubert, B. A. (2002). "L'exposition au risque d'implantation d'ERP: e'le'ments de mesure et d'atte'nuation". Cahier de la Chaire de gestion strate'gique des technologies de l'information, 2(6), (technical paper).

Bhattacharya, R., Devinney, T. M., \& Pillutla, M. M. (1998). "A formal model of trust based on outcomes". Academy of Management Review, 23(3), 459-472. https://doi.org/10.5465/amr.1998.926621

Blumberg, B., Cooper, D. R., \& Schindler, P. S. (2005). Business research methods. Maidenhead, UK: McGraw-Hill.

Bosilj Vuks`ic', V., \& Spremic', M. (2004). "Case study of PLIVA pharmaceuticals inc - aligning ERP system implementation with business process change". Information Technology Interfaces, 26th International Conference on ITI, Cavtat, Croatia, 10 June.

Bradford, M., \& Florin, J. (2003). Examining the role of innovation diffusion factors on the implementation success of enterprise resource planning systems. International Journal of Accounting Information Systems. 4(3), 205-225. https://doi.org/10.1016/S1467-0895(03)00026-5

Caron, M., Jarvenpaa, S. L., \& Stoddard, D. B. (1994). "Business reengineering at CIGNA corporation: experience and lessons learned from the first five years". MIS Quarterly, 18(3), 233-250. https://doi.org/10.2307/249617

Chen, S., \& Li, C. (2005). "An empirical study of the relationship of enterprise conditions and ERP implementation effect". Science and Technology Management Research, 7, 69-72.

Creswell, J. (2009). Research design: Qualitative, quantitative, and mixed methods approaches. 3rd Edn., Thousand Oaks: Sage Publications.

Damijan, Ž., Andrej, K., Mojca, I. Š. (2009). "The influence of business process management and some other CSFs on successful ERP implementation". Business Process Management Journal, 15(4), 588-608. https://doi.org/10.1108/14637150910975552

Davenport, T. (2000). Mission Critical, Harvard Business School Press, Boston, MA.

Davenport, T., \& Linder, J. (1994). Information Management Infrastructure: the new competitive weapon? Proceedings of the System Sciences. Proceedings of the Twenty Seventh Hawaii International Conference on. pp. 885-896.

Davison, R. (2002). "Cultural complications of ERP". Communications of the ACM, 45(7), 109-111. https://doi.org/10.1145/514236.514267

Dong, W. K., Young, J. S., \& Robert, M. (2018) "Investigating the relationship between supply chain innovation, risk management capabilities and competitive advantage in global supply chains". International Journal of Operations \& Production Management, 38(1), 2-21. https://doi.org/10.1108/IJOPM-06-2015-0390

Donovan, M. (1999). "Successful ERP implementation the first time". Midrange ERP, August, available at: www.midmidrangeerp.com

Ein-Dor, P., \& Segev, E. (1978). "Organizational context and the success of management information systems". Management Science, 24(10), 1064-1077. https://doi.org/10.1287/mnsc.24.10.1064

Esteves-Souza, J., \& Pastor-Collado, J. A. (2000). "Towards the unification of critical success factors for ERP implementations". Available at: www.army.mil/escc/docs/bit2000.pdf (accessed January 26, 2007).

Gargeya, V. B., \& Brady, C. (2005). "Success and failure factors of adopting SAP in ERP system implementation". Business Process Management Journal, 11(5), 501-516.

https://doi.org/10.1108/14637150510619858 
Goel, S., Kiran, R., \& Garg, D. (2011). "A framework for efficient enterprise resource planning (ERP) implementation in technical educational institutions". African Journal of Business Management, 5(34), 13197-13204.

Goffman, E. (1971). Relations in Public, Basic Books, New York, NY.

Grover, V., Jeong, S. R., Kettinger, W. J., \& Teng, J. T. C. (1995). "The implementation of business process reengineering". Journal of Management Information Systems, 12(1), 109-144. https://doi.org/10.1080/07421222.1995.11518072

Hair, J., Anderson, R., Tatham, R., \& Black, W. (1998). Multivariate data analysis. 5th Edn., New Jersey: Prentice-Hall International Inc.

Hall, G., Rosenthal, J., \& Wade, J. (1993). "How to make reengineering really work". Harvard Business Review, 71(6), 119-131.

Hammer, M., \& Champy, J. (2003). Reengineering the Corporation: A Manifesto for Business Revolution, HarperBusiness Essentials, New York, NY.

Harmon, P. (2007). Business Process Change: A guide for Business Managers and BMP and Six Sigma Professionals. Elsevier/Morgan Kaufmann Publ, Amsterdam.

Heider, F. (1958). The Psychology of Interpersonal Relations, Wiley, New York, NY.

Huang, S. M., Chang, I. C., Li, S. H., \& Lin, M. T. (2004). “Assessing risk in ERP projects: identify and prioritize the factors". Industrial Management \& Data Systems, 104(8), 681-688. https://doi.org/10.1108/02635570410561672

Ifinedo, P., Rapp, B., Ifinedo, A., \& Sundberg, K. (2010). Relationships among ERP post implementation success constructs: An analysis at the organizational level. Computers in Human Behavior. 26(5), 1136-1148. https://doi.org/10.1016/j.chb.2010.03.020

Indihar, S., “ Temberger, M., \& Kovac ${ }^{\sim}$ ic", A. (2008). "The role of business process modelling in ERP implementation projects". Proceedings of the 10th International Conference on Computer Modelling and Simulation, 1-3April 2008,Emmanuel College, Cambridge, England, pp. 260-265.

IndiharS ` temberger, M., \& Kovac `ic ${ }^{`}$, A. (2006). "Kako lahko informatiki prispevajo k izboljs`anju partnerstva z managementom". Uporabna informatika, 14(4), 196-208.

Ireland, R. D., \& Webb, J.W. (2007). "A multi-theoretic perspective on trust and power in strategic supply chains". Journal of Operations Management, 25(2), 482-497. https://doi.org/10.1016/j.jom.2006.05.004

Jacobson, S., Shepherd, J., D'Aquila, M., \& Carter, K. (2007). "The ERP market sizing report, 2006-2011". available at: www.sap.com/solutions/business-suite/erp/pdf/AMR_ERP_ Market_Sizing_2006-2011.pdf (accessed November 24, 2007).

Jarrar, Y. F., Al-Mudimigh, A., \& Zairi, M. (2000). "ERP implementation critical success factors-the role and impact of business process management". Proceedings of the 2000 IEEE International Conference on Management of Innovation and Technology, pp. 122-7, available at: IEEE Xplore (accessed February 10, 2007).

Klaus, H., Rosemann, M., \& Gable, G. G. (2000). “What is ERP?”. Information Systems Frontier, 2(2), 141-162. https://doi.org/10.1023/A:1026543906354

Kouki, R., Pellerin, R., \& Poulin, D. (2007). Going beyond ERP implementation: An ERP assimilation cross-case analysis. CIRRELT.

Kouki, R., Poulin, D., \& Pellerin, R. (2010). The impact of contextual factors on ERP assimilation: Exploratory findings from a developed and a developing country. Journal of global information technology management, 13(1), 28-55. https://doi.org/10.1080/1097198X.2010.10856508

Kovac`ič ${ }^{`}$, A., \& Bosilj-Vuks`ic', V. (2005). Management poslovnih procesov: Prenova in informatizacija poslovanja s praktic`nimi primeri, GV zaloz`ba, Ljubljana.

La Rock, N. (2003). "Examining the relationship between business process reengineering and information technology". Available at: http://faculty.ed.umuc.edu/,meinkej/inss 690/larock.pdf (accessed February 03, 2007).

Lok, P., Hung, R. Y., Walsh, P., Wang, P., \& Crawford, J. (2005). "An integrative framework for measuring the extent to which organizational variables influence the success of process improvement programmes". The 
Journal of Management Studies, 42(7), 1357-1381. https://doi.org/10.1111/j.1467-6486.2005.00547.x

Lu, C. S., Lai, K. H., \& Cheng, T. C. E. (2005). "An evaluation of web site services in liner shipping in Taiwan". Transportation, 32(3), 293-318. https://doi.org/10.1007/s11116-004-8245-8

Lu, C. S., Lai, K. H., \& Cheng, T. C. E. (2007). "Application of structural equation modelling to evaluate the intention of shippers to use internet services in liner shipping". European Journal of Operational Research, 180(2), 845-867. https://doi.org/10.1016/j.ejor.2006.05.001

Lun, Y. H. V., Wong, W. Y. C., Lai, K. H., \& Cheng, T. C. E. (2008). "Institutional perspective on the adoption of technology for the security enhancement of container transport". Transport Reviews, 28(1), 21-33. https://doi.org/10.1080/01441640701358804

Luo, W., \& Strong, D. M. (2004). "A framework for evaluating ERP implementation choices". IEEE Transactions on Engineering Management, 51(3), 322-333. https://doi.org/10.1109/TEM.2004.830862

Mabert, V. A., Soni, A., \& Venkataramanan, M. A. (2003). "Enterprise resource planning: managing the implementation process". European Journal of Operational Research, 146(2), 302-314. https://doi.org/10.1016/S0377-2217(02)00551-9

Makris, S., Xanthakis, V., Mourtzis, D., \& Chryssolouris, G. (2008). "On the information modeling for the electronic operation of supply chains: a maritime case study". Robotics and Computer-Integrated Manufacturing, 24(1), 140-149. https://doi.org/10.1016/j.rcim.2006.08.004

Markus, M. L., Axline, S., Petrie, D., \& Tanis, S. C. (2000). "Learning from adopters' experiences with ERP: problems encountered and success achieved". Journal of Information Technology, 15(4), 245-266. https://doi.org/10.1080/02683960010008944

Metaxiotis, K., Zafiropoulos, I., Nikolinakou, K., \& Psarras, J. (2005). "Goal directed project management methodology for the support of ERP implementation and optimal adaptation procedure". Information Management and Computer Security, 13(1), 55-71. https://doi.org/10.1108/09685220510582674

Mokhtarian, P. L. (2004). "A conceptual analysis of the transportation impacts of e-commerce". Transportation, 31(3), 257-284. https://doi.org/10.1023/B:PORT.0000025428.64128.d3

Muscatello, J. R., Small, M. H., \& Chenz, I. J. (2003). "Implementing enterprise resource planning (ERP) systems in small and midsize manufacturing firms". International Journal of Operations and Production Management, 23(8), 850-871. https://doi.org/10.1108/01443570310486329

Nejib, B. M. (2013). Determinants of Post Implementation Success of ERP In Tunisian Companies: An Empirical Study of The Moderating Role of The Technical Fit. International Review of Management and Business Research. 2(4), 1101.

Ngai, E. W. T., Law, C .C. H., \& Wat, F. K. T. (2008). "Examining the critical success factors in the adoption of enterprise resource planning”. Computers in Industry, 59(6), 548-564. https://doi.org/10.1016/j.compind.2007.12.001

Olivier, F., Mario, B., \& Robert, P. (2009). "ERP implementation through critical successfactors' management". Business Process Management Journal, 15(3), 371-394. https://doi.org/10.1108/14637150910960620

Ononiwu, C. G. (2013). A Delphi Examination of Inhibitors of The Effective use of Process Industry Enterprise Resource Planning (Erp) Systems: A Case Study of New Zealand's Process Industry. Electronic Journal of Information Systems Evaluation, 16(2).

Pallant, J. (2005). SPSS survival manual: A step guide to data analysis using SPSS for windows version 12. Chicago, Illinois: Open University Press.

Pan, M., \& Jang, W. Y. (2008). "Determinants of the adoption of enterprise resource planning within the technology organization environment framework: Taiwan's communications industry". Computer and Information Science, 48(3), 94-102.

Paradice, D. (2009). Emerging Systems Approaches in Information Technologies: Concepts, Theories, and Applications: Concepts, Theories, and Applications. IGI Global.

Parr, A., \& Shanks, G. (2000). "A model of ERP project implementation”. Journal of Information Technology, 15(4), 289-303. https://doi.org/10.1080/02683960010009051

Po-Hsing, T., \& Chun-Hsiung, L. (2015). "Supply chain integration, information technology, market orientation and firm performance in container shipping firms". The International Journal of Logistics Management, 
26(1), 82-106. https://doi.org/10.1108/IJLM-09-2012-0088

Premkumar, G., \& Ramamurthy, K. (1995). "The role of inter-organizational and organizational factors on the decision mode for adoption of inter-organizational systems". Decision Science, 26(3), 303-336. https://doi.org/10.1111/j.1540-5915.1995.tb01431.x

Princely, I. (2008). "Impacts of business vision, top management support, and external expertise on ERP success". Business Process Management Journal, 14(4), 551-568. https://doi.org/10.1108/14637150810888073

Rizzo, F., Barboni, M., Faggion, L., Azzalin, G., \& Sironi, M. (2011). "Improved security for commercial container transports using an innovative active RFID system". Journal of Network and Computer Applications, 34(3), 846-852. https://doi.org/10.1016/j.jnca.2010.04.006

Rotter, J. B. (1954). Social Learning and Clinical Psychology, Prentice-Hall, New York, NY. https://doi.org/10.1037/10788-000

Rotter, J. B. (1971). "Generalized expectancies for interpersonal trust". American Psychologist, 26(5), 443-450. https://doi.org/10.1037/h0031464

Schniederjans, D., \& Yadav, S. (2013). "Successful ERP implementation: an integrative model". Business Process Management Journal, 19(2), 364-398. https://doi.org/10.1108/14637151311308358

Schniederjans, D., \& Yadav, S. (2013). Successful ERP implementation: an integrative model. Business Process Management Journal. 19(2), 364-398. https://doi.org/10.1108/14637151311308358

Shahin, D., \& Sulaiman, A. (2011). "The influence of organizational factors on successful ERP implementation". Management Decision, 49(6), 911-926. https://doi.org/10.1108/00251741111143603

Shao, Z., Feng, Y., \& Liu, L. (2012). The mediating effect of organizational culture and knowledge sharing on transformational leadership and Enterprise Resource Planning systems success: An empirical study in China. Computers in Human Behavior. 28(6), 2400-2413. https://doi.org/10.1016/j.chb.2012.07.011

Shaul, L., \& Tauber, D. (2013). Critical success factors in enterprise resource planning systems: Review of the last decade. ACM Computing Surveys (CSUR), 45(4), 55. https://doi.org/10.1145/2501654.2501669

Soltan, E, Jusoh, A, \& Bagheri B, (2015). "An Integrative Environmental Framework for a Better Enterprise Resource Planning Post-Implementation Success". Mediterranean Journal of Social Sciences. November 2015.

Taube, L. R., \& Gargeya, V. B. (2005). "An analysis of ERP system implementions: a methodology". The Business Review, Cambridge, 4(1), 1-6.

Thi, L. S., Lim, H. E., \& Al-Zoubi, M. I. (2014). Estimating Influence of TOE Factors on E-Government Usage: Evidence of Jordanian Companies. International Journal of Business and Society, 15(3), 413

Thong, J. Y. L., Yap, C., \& Raman, K. S. (1996). "Top management support, external expertise and information systems implementation in small businesses". Information Systems Research, 7(2), 248-267. https://doi.org/10.1287/isre.7.2.248

Tilley, S. (1995). "Perspectives on legacy system reengineering". Available at: www.sei.cmu.edu/ reengineering/lsysree.pdf (accessed March 26, 2007).

Umble, E. J., \& Umble, M. M. (2002). “Avoiding ERP implementation failure”. Industrial Management, 44(1), 25-33.

Umble, E. J., Haft, R. R., \& Umble, M. M. (2003). "Enterprise resource planning: implementation procedures and critical success factors". European Journal of Operational Research, 146(2), 241-257. https://doi.org/10.1016/S0377-2217(02)00547-7

Vlachos, N. (2006). "Key aspects for a successful ERP implementation in greece", paper presented at the 3rd International Conference on Enterprise Systems and Accounting (ICESAcc'06), Santorini Island, Greece, June 26-27.

Wang, E. T. G., \& Chen, J. H. F. (2006). "Effects of internal support and consultant quality on the consulting process and ERP system quality". Decision Support System, 42(2), 1029-1041. https://doi.org/10.1016/j.dss.2005.08.005

White, R. E. (2008). Post-implementation evaluation of enterprise resource planning (ERP) systems. University of North Texas. 
Wilson, C. V. (2012). Postimplementation Planning and Organizational Structure of Enterprise Resource Planning Systems. Walden University.

Wong, C. W. Y., Lai, K. H., \& Ngai, E. W. T. (2009). "The role of supplier operational adaptation on the performance of IT-enabled transport logistics under environmental uncertainty". International Journal Production Economics, 122(1), 47-55. https://doi.org/10.1016/j.ijpe.2008.12.023

Yang, C., \& Su, Y. F. (2009). The relationship between benefits of ERP systems implementation and its impacts on firm performance of SCM. Journal of Enterprise Information Management, 22(6), 722-752. https://doi.org/10.1108/17410390910999602

Yen, D. C., Chou, D. C., \& Chang, J. (2002). "A synergic analysis for web-based enterprise resources-planning systems". Computer Standards \& Interfaces, 24(4), 337-346. https://doi.org/10.1016/S0920-5489(01)00105-2

Yen, H. R., \& Sheu, C. (2004). "Aligning ERP implementation with competitive priorities of manufacturing firms: an exploratory study". International Journal of Product Economics, 92(3), 207-220. https://doi.org/10.1016/j.ijpe.2003.08.014

Zafiropoulos, I., Metaxiotis, K., \& Askounis, D. (2005). "Dynamic risk management system for the modeling, optimal adaptation and implementation of an ERP system". Information Management and Computer Security, 13(3), 212-234. https://doi.org/10.1108/09685220510602031

Zairi, M., \& Sinclair, D. (1995). "Business process re-engineering and process management: a survey of current practice and future trends in integrated management". Management Decision, 33(3), 3-16. https://doi.org/10.1108/00251749510085021

Zhang, Z., Lee, M. K. O., Huang, P., Zhang, L., \& Huang, X. (2005). "A framework of ERP systems implementation success in China: an empirical study". International Journal of Production Economics, 98(1), 56-80. https://doi.org/10.1016/j.ijpe.2004.09.004

Zhu, K., \& Kraemer, K. L. (2005). Post-adoption variations in usage and value of e-business by organizations: cross-country evidence from the retail industry. Information Systems Research, 16(1), 61-84. https://doi.org/10.1287/isre.1050.0045

Zhu, K., Kraemer, K. L., \& Dedrick, J. (2004). Information technology payoff in e-business environments: An international perspective on value creation of e-business in the financial services industry. Journal of Management Information Systems, 21(1), 17-54. https://doi.org/10.1080/07421222.2004.11045797

Zhu, K., Kraemer, K., \& Xu, S. (2003). "Electronic business adoption by European firms: a cross country assessment of the facilitators and inhibitors". European Journal of Information Systems, 12(4), 251-268. https://doi.org/10.1057/palgrave.ejis.3000475

Zhu, Y., Li, Y., Wang, W., \& Chen, J. (2010). What leads to post-implementation success of ERP? An empirical study of the Chinese retail industry. International Journal of Information Management, 30(3), 265-276. https://doi.org/10.1016/j.ijinfomgt.2009.09.007

Zucker, L. G. (1986). "Production of trust: institutional sources of economic structure", in Staw, B.M. and Cummings, L.L. (Eds). Research in Organizational Behavior, JAI Press, Greenwich, pp. 53-111.

\section{Copyrights}

Copyright for this article is retained by the author(s), with first publication rights granted to the journal.

This is an open-access article distributed under the terms and conditions of the Creative Commons Attribution license (http://creativecommons.org/licenses/by/4.0/). 